\title{
Activism: A Strong Predictor of Proactive Environmentally Friendly Buying Behavior in Turkey
}

\author{
Ahu Ergen ${ }^{\mathrm{a}}$, Filiz Bozkurt ${ }^{\mathrm{b}}$, Caner Giray ${ }^{\mathrm{c}}$ \\ ${ }^{a}$ PhD, Bahçeşehir Üniversitesi, Abide-i Hürriyet Tepesi No.316 Şişli, İstanbul 34363,Turkey \\ ${ }^{b}$ Lecturer, Doğuş Üniversitesi, Acıbadem, Kadıköy, İstanbul 34722, Turkey \\ ${ }^{c}$ PhD in Marketing, Lecturer, İstanbul, Turkey
}

\begin{abstract}
The market for environmentally friendly products in Turkey is growing, and marketing experts are trying to understand the behavior of the consumers in this market with the help of variables such as demographic factors, information, attitudes, values and life styles. This study analyzes the effects of environmental activism, environmental knowledge and the perceived seriousness of environmental problems on green buying behavior. The study involved 516 Turkish consumers, over eighteen years of age. The results show that environmental activism, environmental knowledge and the perceived seriousness of environmental problems are all meaningful factors in environmentally friendly buying behavior. It was found that the most explanatory variables are environmental activism for proactive environmentally friendly buying behavior and the perceived seriousness of environmental problems for optional environmentally friendly buying behavior. The study is significant since it will offer insights for green marketing experts who especially target specific segments as activists, voluntary simplifiers or green consumers in Turkey.
\end{abstract}

Keyword: environmental activism; environmental knowledge; environmental problems; buying behavior.

JEL Code: M3

\section{C) 2014 Published by SSBFNET}

\section{Introduction}

As a result of increasing industrial activity and individual consumption habits since the industrial revolution, environmental deterioration has become a growing global problem. Today, due to the depletion of natural resources and disturbed ecological balances, consumers are becoming more sensitive about social issues, their environmental awareness is increasing, and they are starting to care more about whether their choices of products and brands benefits or harms the planet.

\footnotetext{
${ }^{\text {a }}$ Corresponding author. Ahu Ergen, Tel.: +90 2123810658.
} 
In the literature, there are studies showing that many social, cultural and personal factors such as perceived seriousness of environmental problems, knowledge on environmental issues, environmental concern, values, life styles and demographical factors influence environmentalist behavior. The oldest model that attempts to explain environmental friendly behavior asserts that environmental knowledge leads directly to environmentalist attitude, and that environmentalist attitude leads directly to environmentalist behavior. In Belief, Attitude, Intention, and Behavior: An Introduction to Theory and Research, Fishbein \& Ajzen (1975) showed that, together with subjective norms, attitudes can explain intentions towards behavior, and that intention is a direct predictor for behavior (Kocagoz \& Dursun 2010). On the other hand, Schwartz's (1977) altruistic behavior model emphasizes the fact that individuals behave under the influence of personal norms. In this model behavior can be explained by the interrelationships of four main structures: personal norms, social norms, awareness of consequences and taking responsibility. The central idea of the model is that the effect of social norms on individual behavior is not direct. Fietkau \& Kessel's (1981) ecological behavior model used psychological and sociological factors to explain environmentalist behavior, while Kollmus \& Agyeman (2002) emphasized the importance of personality traits, value systems, obstacles and environmental awareness.

Environmentally friendly buying behavior is also referred to as green buying behavior, green consumption, ecological buying or sustainable consumption, and it has been adopted by consumer groups in many markets in conjunction with the development of green marketing. Green marketing began to gain importance in the 1980s, grew prominent especially after the year 2000 and is currently expanding towards Asia due to increasing environmental threats (Lee 2008). Predicting environmentally friendly buying behavior, involves many factors such as environmental knowledge, environmental concern, demographical variables, values and life styles, together or independently. This paper examines the environmentally friendly buying behavior of consumers in Turkey and the factors that influence it.

\section{Literature Review}

\subsection{Environmental Knowledge and the Perceived Seriousness of Environmental Problems}

Environmental knowledge is defined as, "a general knowledge of facts, concepts, and relationships concerning the natural environment and its major ecosystems" (Fryxell \& Lo 2003). Although it is a useful variable for predicting environmentalist behavior (Finisterra \& Raposo 2010), knowledge of environmental issues is considered to be a precondition that is necessary, but not sufficient, at least on its own (Bamberg \& Moser 2007). Other factors that are thought to positively or negatively affect environmentalist behavior include demographical factors, external factors (for instance, institutional, economical, social and cultural factors) and internal factors (motivation, awareness, values, attitudes, emotions, responsibilities and priorities, etc.) (Kollmuss \& Agyeman 2002). Environmental knowledge can be divided into two categories: environmental and behavioral knowledge. Environmental knowledge is defined as the abstract knowledge that is a precondition for action. It implies a general knowledge of the state of the environment and an awareness of environmental problems such as waste disposal. On the other hand, behavioral knowledge is the concrete knowledge that does in fact lead to action, such as knowing how and where to recycle waste. There are findings that show a strong relationship between concrete knowledge and behavior (Barr 2007). It has also been 
suggested that gender is an important determinant for levels of environmental knowledge. A study comparing environmental knowledge levels in six countries found that in all of them, men have higher levels of environmental information than women (Gendall \& Smith 1995). Another study of Egyptian consumers shows that ecological knowledge, concern and attitude variables that effect green buying behavior are differentiated by gender, and that environmental knowledge is lower among women (Mostafa 2007). A study in the U.S. determined that women have greater scientific knowledge of climate change than do men. However, women underestimate their climate change knowledge more than men do. Women also express slightly greater concern about climate change than men (McCright 2010). In the U.S. and the U.K., the fact that environmental problems affect the buying and food consumption decisions of six out of ten consumers make green consumers' environmental knowledge very important for the whole supply chain, especially for retailers (Ottman 1992).

In the 1980s the Bhopal chemical gas leak incident, the Chernobyl nuclear disaster and the Exon-Valdez oil spill were important environmental disasters that drew the public's attention to environmental protection issues (Alniacik \& Yilmaz 2008). Environmental problems are increasing day by day along with social and economical development. According to Kilic (2006) the fact that global warming, ocean pollution, desertification, erosion, rising populations and food insecurity prevail in many countries, while problems with resource allocation are worsening, proves that the environmental policies of modern societies are failing. Not only that, but the fact that developing countries are adopting the Western development model means that environmental problems will continue to increase in the future. Research shows that environmental problems take up increasing space on the public's agenda, that people believe that environmental problems will become more serious with time, that consumers are purchasing certain products and not purchasing others for reasons related to the environment, and that they are even willing to pay more to purchase environmentally friendly products. The increasing awareness among consumers about environmental problems has led many companies to develop new strategies. An increase has been observed in the number of firms that frequently make environmental claims in their advertising campaigns against their rivals (Phau \& Ong 2007). In a study exploring the effect of education on environmental concern for a sample of 18 countries, results showed that the effect of education on environmental concern initially rises with cohorts born early in the twentieth century, then levels off and peaks for cohorts born around 1940, and subsequently becomes increasingly weaker for younger cohorts (Nawrotzki \& Pampel 2013). Thus the perceived seriousness of environmental problems is considered to be one of the personal factors that may influence buying behavior.

\subsection{Environmental Activism}

Rising environmentalism trends have led to a remarkable increase in the environmentally friendly attitudes and behavior of consumers. According to Crane (2010) consumers demonstrate their power over producers through involvement in social movements and individual shopping decisions. In terms of involvement in social movements, we can talk about environmental activism. This notion has been a research subject in many disciplines including psychology, sociology, political science and education (Dono et al. 2010). Meanwhile, individual shopping decisions are defined in the literature as consumer activism. 
According to Seguin et al. (1998), "environmental activists are people who intentionally engage in the most difficult ecological behaviors. They are usually members of environmental groups, are involved in fund raising campaigns or the signing of petitions, write letters to government and to policy makers, and also try to influence people's attitudes and behaviours toward the environment". Hunter et al. (2004) define environmental activism similarly, and they associate activist behavior with activities such as membership in environmentalist groups, participation in petitions, protests and demonstrations. In addition to focused objectives such as forcing target companies to change their behavior, activists also engage in activities with wider objectives such as attracting attention to particular issues, raising funds for organizations or gaining recognition and status (Lenox \& Eesley 2009). Rief's study (2008) describes the political consumerism of social movements that mobilize against global brand names, claiming that it forces producers and retailers to adopt higher environmental and social standards.

O'Shaughnessy \& Kennedy (2010) view activism as having two dimensions: traditional and relational. According to their approach, the activities associated with traditional activism (such as participation in protests and public action campaigns) usually ignore relational activism behavior that does not involve direct action. Relational activism includes the continuous activities that underlie traditional activism. Relational activism is seen as less proactive, and it derives its power from relationships between like-minded people. The effectiveness of relational activism is rising today, with the help of internet and digitalization, social networks and mobile communication.

Stern (2000) divides environmentalist behavior into four subgroups: environmental activism (for instance, involvement in relevant organizations and demonstrations), non-activist behavior in the public sphere (for instance, environmental citizenship or supporting public policy), private sphere environmentalism (e.g., not buying, using or throwing away products that have an environmental impact) and other environmentalist behavior (for example, systemic influences through organizations). He emphasizes that environmental activism stands apart from the others due to its intention to protect the environment. Although they indirectly influence environmental issues by influencing public policy, the impact of activist behavior can be very powerful because public policies have the power to change the behavior of many people and institutions. Moreover, environmental activism should be considered as an element that mobilizes consumer activism, so the fact that activism indirectly affects environmentally friendly buying behavior must definitely be kept in mind. Carrigan \& Attalla (2001) pointed out that consumer activism has increased, and that these kinds of movements significantly harm the business of corporations. However, Lenox \& Eesley's (2009) 19982003 study of environmental activism campaigns shows that powerful groups of capitalists can diminish the impact of movements against them.

Another important aspect of activism is the choice of media. Hollenbeck \& Zinkhan (2006) indicate that anti-brand movements spread very quickly and effectively on the internet without being tied to a specific locality or time frame. Meanwhile, Rauch's (2007) study shows that activists prefer alternative media to institutional media. The findings of this study imply that the planning of environmentally sensitive organizations' communication activities should not ignore alternative media. 


\subsection{Environmentally Friendly Buying Behavior}

What, how and how much consumers are consuming puts pressure on the planet. According to one view, if the consumption of natural resources continues at its current rate, we will need three more planets (Knight 2004). Since the 1990s, when environmental sensitivities became a life style for some people, environmentalist consumers started to constitute an important market segment (Alniacik \& Yilmaz 2008).

Due to the recent financial meltdown, individuals are questioning their consumption more than ever. They are asking questions such as:

"Are we eating too much food? Is it the wrong kind of food? Can we give up beef, which is such an inefficient way to meet our protein needs? Are we consuming too much sugar and salt and butter? Are family members following a healthy diet? Are we driving a fuel efficient car? Do we even need to own a car? Can we save more energy by running of our home with more efficient lighting, solar panels, or by other means? Can we sort trash more efficiently into paper, cans and bottles and waste? (Kotler 2011)”.

Today, for a significant number of consumers, buying behavior means buying environmentally friendly or green products. The most common environmentally friendly types of buying behavior in the literature are: buying products made of recycled materials, buying environmentally friendly soap and detergents, buying products that will have minimum impact on the environment, buying energy efficient products, buying organic, fair trade, local products and avoiding unnecessary packaging and aerosol containers. Although there has been a notable increase in the number of sustainable products and market sectors that allow for sustainable consumption behavior, research findings also reveal that consumers often feel dilemmas when making sustainable product choices. For instance, although $80 \%$ of consumers in the U.S. indicate that protecting the environment affects their buying decisions, only a little more than half of them state that they buy environmentally friendly or recycled products (Gardyn, 2003).

According to Kotler and Keller (2009), the increasing number of green products sold will break consumers' loyalty habits to products that are not green, eliminate skepticism about trying green products and about the quality of these products, and change attitudes towards green products. In a study of environmentally friendly consumer behavior, Crane (2010) emphasizes that positive environmentalist attitudes are widespread, but that these attitudes are not reflected by consumers' behavior. According to the study, the failure to translate attitudes into behavior results from factors such as the high prices of green products, the difficulty of finding them, the difficulty of finding out which product is really environmentally friendly, finding arguments by environmentalists unconvincing. On the other hand, Carrigan \&Attalla (2001) claim that attitudes may not be reflected in behavior for reasons such as not believing that anything will change and having to sacrifice personal comfort. Therefore, research on this subject should keep in mind that individual environmentally friendly buying behavior is shaped by the framework of the social environment and by personal resources. 


\section{Research, Methodology and Application}

The aim of the present study is to investigate the nature of the relationship between environmental activism, the perceived seriousness of environmental problems, environmental knowledge and environmentally friendly buying behavior.

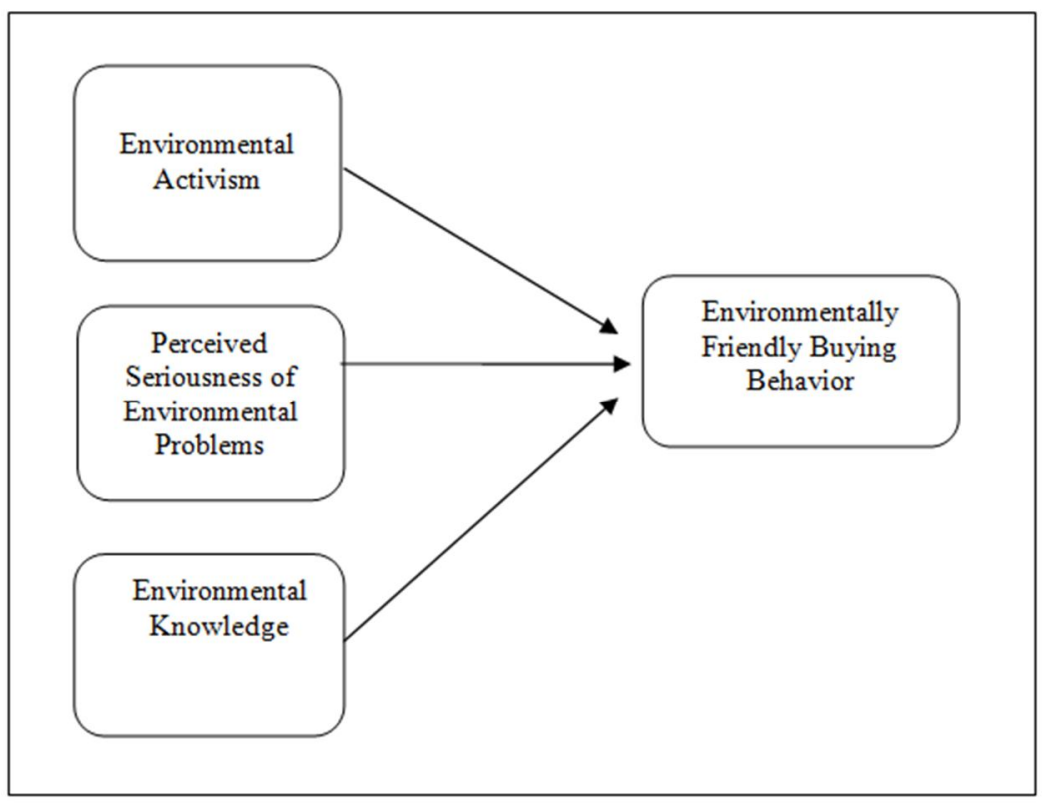

Fig. 1 Model of the proposed relationship between the variables

Based on the literature, the model in Fig. 1 is designed to find out whether environmental knowledge, seriousness of environmental problems and environmental activism predict environmentally friendly buying behavior. The following hypotheses pertain to the model in Fig.1.

Hypothesis 1: Environmental activism will positively predict environmentally friendly buying behavior.

Hypothesis 2: The perceived seriousness of environmental problems will positively predict environmentally friendly buying behavior.

Hypothesis 3: Environmental knowledge will positively predict environmentally friendly buying behavior.

\subsection{Sampling and Data Collection}

For the pre-test, a drop-off survey was conducted with fifty respondents using convenience sampling. According to the pre-test results, some wording was adapted to the Turkish language, and some sentences were simplified. Convenience sampling was used, and 634 responses were collected from respondents over eighteen of age by drop-off survey in Istanbul. However, after eliminating incorrect and incomplete samples, 516 surveys remained for the analysis. Respondents answered items using a 5-point scale. The demographic characteristics of the respondents were measured by a nominal scale. 


\subsection{Measures Used in the Study}

The survey prepared for the research included thirty-two questions. As seen in Table 1 environmental activism has four items measuring environmental activists' interest in and search for information, their collaboration with environmentalist organizations and their active participation in protests in favor of environmental causes. The measure of environmental knowledge has five items. It measures the knowledge of practices that do not harm the environment, knowledge about matters as the greenhouse effect, acid rain or the hole in the ozone layer (Finisterra \& Raposo 2010). The measure of perceived seriousness of environmental problems (Lee 2008) also contains five items. The environmentally friendly buying behavior includes thirteen items (Finisterra \& Raposo 2010; Lee 2008). There are also five questions about socio-demographics.

Table 1. Measures Used in Research

\begin{tabular}{|c|c|c|}
\hline Measure & Developers & Item \\
\hline $\begin{array}{l}\text { Environmentally friendly } \\
\text { buying behavior }\end{array}$ & Paço \& Raposo (2010)., Lee (2008) & 13 \\
\hline Environmental activism & Paço \& Raposo (2010) & 4 \\
\hline Environmental knowledge & Paço \& Raposo (2010) & 5 \\
\hline $\begin{array}{l}\text { Perceived seriousness of } \\
\text { environmental problems }\end{array}$ & Lee (2008) & 5 \\
\hline
\end{tabular}


Table 2. Varimax rotated component matrix for factor analysis of the environmentally friendly buying behavior (EFBB)

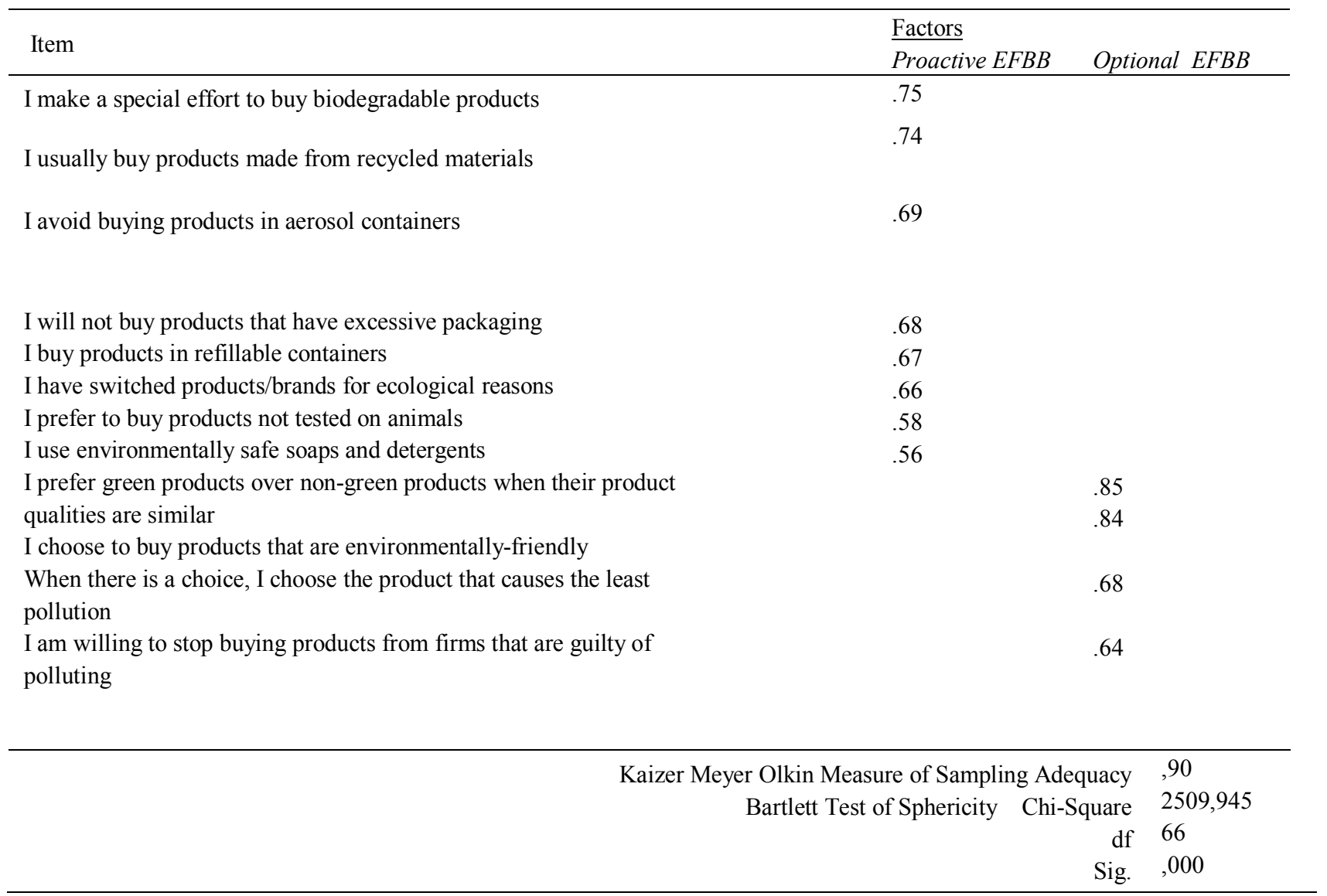

Source: Author's own calculation

\subsection{Descriptive Statistics}

In order to evaluate the participants' socio-demographic profile the questionnaire asked about their gender, age, education, household income and their membership in environmental organizations. This data showed $45 \%$ of the respondents were male and 55\%, female. In terms of age distribution, 38.4\% were in the $18-25$ age groups, while $28.5 \%$ is in the $26-35$ age groups. Of the participants, $62.3 \%$ were single. $47.2 \%$ of the participants have undergraduate, $16 \%$ have graduate and $34.4 \%$ have high school diplomas. Of the participants, 35\% have monthly income of 5,000 TL or more, while $21.4 \%$ have monthly incomes between 2000 and 3000 TL. Finally, 13\% of the participants were members of an environmental organization. These statistics indicate that the participants were young, and well above the Turkish averages in terms of education and income level. 


\section{Research Findings}

An exploratory factor analysis to determine the dimensions of the measures (Table 2), Cronbach's Alpha test for reliability and, to test the hypothesis, Multiple Regression, were conducted using SPSS 19.0. The factor analysis showed that $55.43 \%$ of total variance in environmentally friendly buying behavior items were accounted for by two factors. These factors were identified as proactive and optional environmentally friendly buying behavior. Eight items loaded on the first factor (factor loadings ranged from .56 to .75) accounted for $44.80 \%$ of the total variance among items. Four items loaded on the second factor (from .64 to .85) accounted for $10.63 \%$ of the variance. The first factor, proactive environmentally friendly buying behavior, measures the reactive, specific green behavior (Alpha=.86). The second factor, optional environmentally friendly buying behavior, measures positive attitudes toward green purchasing behavior (Alpha=.80). Environmental activism (Alpha=.77), environmental knowledge (Alpha=.85) and the perceived seriousness of environmental problems (Alpha=.91) were also internally consistent. Tables 3 and 4 show that independent variables (environmental activism, environmental knowledge, perceived seriousness of environmental problems) explain proactive environmentally friendly buying behavior variance by $30 \%$, while they account for $29 \%$ of the optional environmentally friendly buying behavior variance. In other words, $30 \%$ of proactive environmentally friendly buying behavior and $29 \%$ of optional environmentally friendly buying behavior is shaped by the independent variables.

Table 3. Results of regression of independent variables on proactive environmentally friendly buying behavior

\begin{tabular}{lllll}
\hline Predictor & $\mathrm{B}$ & $\mathrm{SE}_{\mathrm{B}}$ & $\mathrm{Beta}$ & $\mathrm{T}$ value \\
\hline & & & & \\
Environmental activism & .388 & .033 & .448 & $11.78^{*}$ \\
Environmental knowledge & .097 & .042 & .087 & $2.28^{*}$ \\
Perceived seriousness of environmental problems & .176 & .034 & .198 & $5.18^{*}$ \\
Adjusted $\mathrm{R}^{2}=0.30{ }^{*} \mathrm{p}<0.05$ & & & & \\
\hline
\end{tabular}

Source: Author's own calculation

Table 4. Results of regression of independent variables on optional environmentally friendly buying behavior

\begin{tabular}{lllll}
\hline Predictor & $\mathrm{B}$ & $\mathrm{SE}_{\mathrm{B}}$ & Beta & T value \\
\hline & & & & \\
Environmental activism & .212 & .33 & .244 & 6.35 \\
Environmental knowledge & .190 & .043 & .170 & 4.40 \\
Perceived seriousness of environmental problems & .318 & .035 & .355 & 9.20 \\
Adjusted $\mathrm{R}^{2}=0.29,{ }^{*} \mathrm{p}<0.05$ & & & & \\
\end{tabular}

Source: Author's own calculation

These findings show that the strongest independent variable that explains proactive environmentally friendly buying behavior is environmental activism (Beta=0,448). Although activism also has an impact on optional environmentalist 
buying behavior (Beta $=0,244$ ), this is much lower than its effect on proactive behavior. We found that environmental knowledge has extremely low explanatory strength, although it is meaningful in explaining both dimensions of environmentally friendly buying behavior (Beta values $=0.087$ and 0.170 ). The perceived seriousness of environmental problems has more of an effect on optional environmentalist buying behavior (Beta=.355) than on proactive environmentalist buying behavior (Beta $=.198$ ). The increase in the perceived seriousness of environmental problems also affects optional environmentalist buying.

In the regression analysis, there are some criteria that indicate a multi-collinearity problem. The first indicator of probable multiple correlation is 0.9 or higher correlation between independent variables. Another indicator is a VIF value higher than 10 (Hair et al. 2010). According to another view, if the correlation between independent variables is larger than 0.7 , multiple correlation should be suspected, and multiple correlation is determined by looking at whether the condition index is larger than 30 (or 15, according to some sources) (Durmus et al. 2011). These values were analyzed, and it was found that there are no multiple correlation problems between independent variables. In conclusion, all three hypotheses are supported and it is proved that independent variables have positive effect on the dependent variable.

\section{Conclusions and Future Directions}

The findings of this study show that activism is the top predictor of Turkish consumers' proactive environmentally friendly buying behavior, followed by the perceived seriousness of environmental problems, and then, by environmental knowledge. Proactive environmentally friendly buying behavior includes actions that require more effort, such as putting more effort into buying biodegradable products, buying recycled products, buying products that are not tested on animals and using environmentally friendly detergents and soaps. This information implies that the environmental sensitivities and inner motivations of activists very effectively lead to proactive behavior. Although only $13 \%$ of the participants are members of an environmental organization, and it is known that environmental activists are still a minority of the population, they constitute an important market sector for environmentally friendly products. We propose that future studies should analyze the effect of the lifestyles and values of activist groups on the marketing of environmentally friendly products.

The other important outcome is that the top predictor for the optional environmentally friendly buying behavior is the perceived seriousness of environmental problems, followed by environmental activism and environmental knowledge. The perceived seriousness of environmental problems predict optional environmentally friendly buying behavior better than the other two variables. Proactive buying behavior, different from optional buying behavior implies a positive attitude, choice and intention, and considering that it is the step before proactive buying, marketing experts should take note of the factors that affect this behavior as much as those that effect proactive behavior. At this point, marketing experts should emphasize the seriousness of the problems, especially with marketing communication tools. After understanding which communication media and narration formats (fear, slice of life, humor etc.) are appropriate for various market segments, increasing the perceived seriousness of environmental problems with suitable methods will have a positive impact on optional environmentally friendly buying. The perceived seriousness of environmental 
problems was the least important factor in affecting teenage consumers' green purchasing decisions in Lee's (2008) research conducted with adolescents in Hong Kong. This research also found that there is a negative relationship between the perceived seriousness of environmental problems and green purchasing behavior. This shows that age and cultural differences may affect the relationship between environmentally friendly buying behavior and the perceived seriousness of environmental problems.

Environmental knowledge is the least influential factor for predicting both environmental behavior categories. In cases where knowledge is not supported by socio-cultural factors, some claim that it is not powerful enough to lead to behavioral change on its own (Kasapoglu 1997). Kollmuss \& Agyeman (2002) assert that there is not a direct relationship between environmental knowledge and environmentalist behavior, that environmental knowledge together with values, attitudes and emotional involvement creates a complex "environmental awareness," and that this awareness is largely dependent on personal values and character traits, while also being influenced by internal and external factors. Including environmental education with creative and participatory programs in curriculums beginning in kindergartens will definitely be an important motivation for positive behavior about environmental issues.

This study has some limitations. First, the study was conducted only in Istanbul where convenience sampling was used. The findings of the study cannot be generalized for Turkey's entire population. Future studies using qualitative research are needed in order to characterize environmental activists in Turkey. On the other hand, as one of only a few studies of green marketing and activism in Turkey, the findings are important and may be enlightening for scholars and green marketing experts.

\section{References}

Alniacik, U., Yilmaz, C. (2008). Deger Yargilari ve Tuketimde Cevreci Egilimler. 13. Ulusal Pazarlama Kongresi Bildiri Kitabi, Adana.

Bamberg, S., \& Moser, G. (2007). Twenty years after Hines, Hungerford and Tomera: A new meta-analysis of psycho-social determinants of pro-environmental behavior. Journal of Environmental Psychology, 27, 14-25.

Barr, S. (2007). Factors Influencing Environmental Attitudes and Behaviors: A U.K. Case Study of Household Waste Management. Environment and Behavior. 39(4), 435-473.

Carrigan, M., \& Attalla, A. (2001). The myth of the ethical consumer: Do ethics matter in purchase behaviour?. Journal of Consumer Marketing, 18(7), 560-578.

Crane, D. (2010). Environmental change and the future of consumption: Implications for consumer identity. Anuario filosófico, 43(2), 353-379.

Dono, J., Webb, J., \& Richardson, B. (2010). The relationship between environmental activism, pro-environmental behaviour and social identity. Journal of Environmental Psychology, 30(2), 178-186.

Durmus, B., Yurtkoyu, E.S., \& Çinko, M. (2011). Sosyal Bilimlerde SPSS'le Veri Analizi. Beta Yayinlari, Istanbul. Fietkau, H.J. \& Kessel, H. (1981). Umweltlernen: Veraenderungsmoeglichkeiten des Umweltbewusstseins. ModellErfahrungen (Koenigstein, Hain). 
Finisterra do Paço, A.M., \& Raposo, M.L.B. (2010). Green consumer market segmentation: empirical findings from Portugal. International Journal of Consumer Studies, 34, 429-436.

Fishbein, M., Ajzen, I. (1975). Belief, Attitude, Intention and Behavior: An Introduction to Theory and Research, Reading, MA: Addison-Wesley.

Fryxell, G., \& Lo, C. (2003). The influence of environmental knowledge and values on managerial behaviors on behalf of the environment: an empirical examination of managers in China. Journal of Business Ethics, 46, 45-59.

Gardyn, R. (2003). Eco-Friend or Foe. American Demographics, 12-13.

Gendall, P., \& Smith, T. (1995). Knowledge of scientific and environmental facts: a comparison of six countries. Marketing Bulletin, 6, 65-73.

Hair, J.F., Black, W.C., Babin, B.J., \& Anderson, R.E. (2010). Multivariate Data Analysis. Pearson, Seventh Ed.

Hollenbeck, C. R., \& Zinkhan, G. M. (2006). Consumer activism on the internet: The role of anti-brand communities. Advances in Consumer Research, 33, 479.

Hunter, L. M., Hatch, A., \& Johnson, A. (2004). Cross National Gender Variation in Environmental Behaviors. Social Science Quarterly, 85(3), 677-694.

Kasapoglu, M.A. (1997). Cevresel Davranis Modeli. Amme Idaresi Dergisi, 30(2).

Kilic, S. (2006). Modern Topluma Ekolojik Bir Yaklasim. Kocaeli Universitesi Sosyal Bilimler Enstitusu Dergisi. 12(2), 108-127.

Knight, A. (2004). Sustainable Consumption the Retailing Paradox. Consumer Policy Review, 14(4), 113-115.

Kocagoz, E., \& Dursun, Y. (2010). Algilanan Davranissal Kontrol, Ajzen'in Teorisinde Nasil Konumlanır? Alternatif Model Analizleri, KMU Sosyal ve Ekonomik Araştirmalar Dergisi, 12(19), 139-152.

Kollmus, A., \& Agyeman, J. (2002). Mind the Gap: Why do people act environmentally and what are the barriers to pro-environmental behavior? Environmental Education Research, 8(3), 239-260.

Kotler, P. \& Keller, K.L. (2009). Marketing Management, Pearson Int. Ed, Thirteenth Ed.

Kotler, P. (2011). Reinventing Marketing to Manage the Environmental Imperative. Journal of Marketing, 75, 132 135 .

Lee, P.K. (2008). Opportunities for green marketing: Young consumers. Marketing Intelligence \& Planning, 26(6), 573-586.

Lenox, M. J., \& Eesley, C. E. (2009). Private environmental activism and the selection and response of firm targets. Journal of Economics \& Management Strategy, 18(1), 45-73.

McCright, A.M. (2010). The effects of gender on climate change knowledge and concern in the American public. Population and Environment, 32, 66-87.

Mostafa, M. (2007). Gender differences in Egyptian consumers' green purchase behaviour: The effects of environmental knowledge, concern and attitude. International Journal of Consumer Studies, 31, 220-229.

Nawrotzki, R.J., \& Pampel, F.C. (2013). Cohort change and the diffusion of environmental concern: a cross-national analysis. Population and Environment, 35, 1-25. 
O'Shaughnessy, S., \& Huddart Kennedy, E. (2010). Relational Activism: Re-imagining Women's Environmental Work as Cultural Change. Canadian Journal of Sociology, 35(4), 551-572.

Ottman, J. (1992). Sometimes consumers will pay more to go green. Marketing News, 6, 16.

Phau, I. \& Ong, D. (2007). An investigation of the effects of environmental claims in promotional messages for clothing brands. Marketing Intelligence \& Planning. 25(7), 772-788.

Rauch, J. (2007). Activists as interpretive communities: Rituals of consumption and interaction in an alternative media audience. Media, Culture \& Society, 29(6), 994-1013.

Rief, S. (2008). Outlines of a critical sociology of consumption: Beyond moralism and celebration. Sociology Compass, 2(2), 560-576.

Schwartz, S. H. (1977). Normative influences on altruism. In L. Berkowitz (Ed.), Advances in experimental social psychology, 221-279. New York: Academic Press.

Seguin, C., Pelletier, L. G., \& Hunsley, J. (1998). Toward a model of environmental activism. Environment and Behavior, 30, 628-652.

Stern, P.C. (2000). New environmental theories: Toward a coherent theory of environmentally significant behavior. Journal of Social Issues, 56(3), 407-424. 